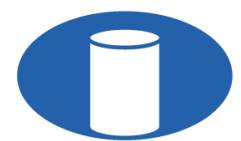

IBRACON Structures and Materials Journal

Revista IBRACON de Estruturas e Materiais

IBRACON

ISSN 1983-4195

ismj.org

ORIGINAL ARTICLE

\title{
Influence of internal sulfate attack on cement paste properties: contamination by pyrite
}

\section{Influência do ataque interno de sulfatos em pastas cimenticias: contaminação por pirita}

\author{
Ana Paula Brandão Capraro ${ }^{\mathrm{a}}$ \\ Juarez Hoppe Filho ${ }^{\mathrm{b}}$ \\ Marcelo Henrique Medeiros ${ }^{\mathrm{a}}$
}

${ }^{a}$ Universidade Federal do Paraná - UFPR, Programa de Pós-graduação em Engenharia Civil - PPGECC, Curitiba, PR, Brasil

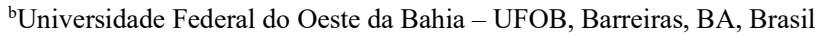

Received 30 August 2020

Accepted 08 March 2021

\begin{abstract}
The objective of this work was to evaluate the influence of the presence of sulfate in the microstructure and compressive strength of cement pastes. The lack of availability of more suitable aggregates, for reasons of distance or costs, sometimes leads to the use of materials that contain sulfate in their composition, which is harmful to cement mixtures. Currently, there are normative recommendations that limit the content of contaminants in the aggregates. However, there are still divergences as to the content that does not damage the concrete. In order to discuss the levels presented in the standards and the values above those allowed by them, tests were carried out on cementitious compounds contaminated by pyrite in different levels of sulfates $\left(0.0 \%, 0.5 \%, 1.0 \%\right.$ and $5.0 \%$ of $\left.\mathrm{SO}_{3}\right)$. SEM, XRD, compressive strength, ultrasonic pulse velocity and porosity analyses were performed in samples at different ages until 720 days of age. During early ages until the first year, the most contaminated samples presented an increase in their strength $(1.0 \%$ and $5.0 \%$ of $\mathrm{SO}_{3}$ ). This behavior was explained by SEM, XRD and porosity analyses by filling the pores with products of sulfate attack, such as ettringite. At the end of the tests (720 days) the series that presented the lowest compressive strength, the presence of cracks and large amounts of ettringite was the one that had $5.0 \% \mathrm{SO}_{3}$ contamination, proving the importance of a normative limit content.
\end{abstract}

Keywords: sulfate, normative limit content, porosity, ettringite, internal sulfate attack.

Resumo: O objetivo deste trabalho foi avaliar a influência da presença de sulfato na microestrutura e resistência à compressão de pastas de cimento. Por vezes, a falta de disponibilidade de agregados mais adequados, por razões de distância ou custos, leva à utilização de materiais que contenham em sua composição a presença de sulfato, prejudicial às misturas de cimento. Atualmente existem recomendações normativas que limitam os teores de contaminação dos agregados, entretanto, ainda existem divergências quanto ao teor que não agride o concreto. A fim de discutir os teores apresentados nas normas e também os valores acima dos permitidos por elas, foram realizados ensaios em compostos cimentícios contaminados por diferentes teores de sulfatos $(0,0 \%, 0,5 \%, 1,0 \%$ e 5,0\% de $\mathrm{SO}_{3}$ ). As análises de $\mathrm{MEV}, \mathrm{DRX}$, resistência à compressão, velocidade de ultrassom e porosidade foram realizadas em diferentes idades, até 720 dias de idade, nas amostras. Durante as primeiras idades, até o primeiro ano, as amostras mais contaminadas apresentaram aumento em sua resistência (1,0\% e 5,0\% de $\left.\mathrm{SO}_{3}\right)$. Este comportamento foi explicado pelas análises de MEV, DRX e porosidade pelo preenchimento dos poros por produtos do ataque de sulfato, como a etringita. Ao final dos ensaios (720 dias) a série que apresentou menor resistência à compressão, presença de fissuras e grande quantidade de etringita foi a que apresentou $5,0 \%$ de contaminação de $\mathrm{SO}_{3}$, comprovando a importância de um teor limite normativo.

Palavras-chave: sulfato, teor limite normativo, porosidade, etringita, resistência à compressão e ataque interno de sulfatos.

How to cite: A. P. B. Capraro, J. Hoppe Filho, and M. H. Medeiros, "Influence of internal sulfate attack on cement paste properties: contamination by pyrite," Rev. IBRACON Estrut. Mater., vol. 14, no. 6, e14606, 2021, https://doi.org/10.1590/S1983-41952021000600006 


\section{INTRODUCTION}

Internal sulfate attack (ISA) has been considered a serious degradation in concrete structures [1]. The degradation of concrete due to the presence of iron sulfides (such as pyrite and pyrrhotite) in aggregates has been widely studied in recent years [2]. Iron sulfides are common minor constituents in many rock types in various regions in the world. They have been implicated in causing damage in concrete, such as expansion [3].

The condition of the environment may favor the oxidation of the sulfide, and, consequently, the occurrence of the attack. Casanova et al. [4] presented some factors that favor the kinetics of the reaction, which are: oxygen and humidity availability, strongly acidic conditions ( $\mathrm{pH}$ typically lower than 4 ), surface area, and iron content.

The internal sulfate attack is caused by the reaction of sulfate ions, present in the aggregates of concrete, with the cement products. The attack mechanism involves several chemical reactions that may generate products such as ettringite, gypsum and thaumasite [5], [6].

The study of the products formed by the attack and the form of their occurrence is of extreme importance, since these cause modifications in the matrix of the cementitious compounds [6]. Schmidt et al. [7] comparatively studied the expansions caused by the deleterious products originated from the presence of pyrite and pyrrhotite in the cement compounds. It was verified that the contaminated aggregates caused expansions in the cement pastes, and the results were close to pyrite and pyrrhotite.

Aggregates contaminated by sulfides are considered unsuitable for use in concrete structures [8]; however, specific situations of distance and lack of more adequate inputs make its use necessary. Considering the consequences of the use of contaminated aggregates, their utilization is restricted by most international standards [4]. However, the limited content of the standards differs from one another. The ACI [9], for example, allows the use of contaminated aggregate if the contamination is less than $0.5 \% \mathrm{SO}_{3}$ of the total aggregate mass. The French standard [10] allows the contamination value to be less than $1.0 \% \mathrm{SO}_{3}$. The Brazilian standard [11] limits the aggregate content to $0.1 \% \mathrm{SO}_{4}$, and if the content is greater than this, the sum of all the constituents of the concrete cannot exceed $0.2 \% \mathrm{SO}_{4}$.

In Brazil, there is a real example of the need to adopt a maximum contamination content for the construction of the Irapé Hydroelectric Plant in Minas Gerais. The analysis of the rock masses indicated the presence of pyrite between 4 to $10 \%$ of the total volume. The use of the aggregates was conditioned to the limit of $0.5 \%$ sulfur in relation to the total mass of the aggregates [12].

The degradation of the concrete produced with aggregate contaminated by sulfide minerals is the result of the interaction of the contaminant with the Portland cement paste. Therefore, this research aimed to illustrate the effects of the internal sulphatic reaction by evaluating the behavior of cementitious composites with the addition of pyrite $\left(\mathrm{FeS}_{2}\right)$. In this context, the aim of this work was to evaluate the influence of the presence of sulfates, in different contents, in the microstructure and compressive strength of cement pastes. For this purpose, the two limits suggested by the standards cited $\left(0.5 \%\right.$ and $\left.1.0 \% \mathrm{SO}_{3}\right)$, one above that mentioned by them $\left(5.0 \% \mathrm{SO}_{3}\right)$ and one reference $\left(0.0 \% \mathrm{SO}_{3}\right)$ were considered.

\section{LITERATURE REVIEW}

In nature there are geological formations of endogenous and metamorphic species that contain the presence of sulfides, most often as pyrite and pyrrhotite. Figure 1 shows the image of an aggregate particle with evident and proven pyrite contamination. The use of these materials as aggregates for concrete causes deleterious reactions, as these minerals are unstable in the presence of water [13].

The deleterious reactions begin with the oxidation of the sulfide mineral in the presence of water and oxygen, causing the formation of iron hydroxide and sulfuric acid [14]. As an example, Equation 1 presents the oxidation of pyrite, a material used as a contaminant in this study.

$$
\mathrm{FeS}_{2}+\mathrm{H}_{2} \mathrm{O}+\frac{7}{2} \mathrm{O}_{2} \rightarrow \mathrm{FeSO}_{4}+\mathrm{H}_{2} \mathrm{SO}_{4}
$$

The oxidation of sulfides triggers a series of chemical reactions in the compound, forming products with greater volumes than the initial volume of the materials [15]. The formation of ettringite, for example, generates dimensional variation, internal stresses and cracks in the concrete, compromising the durability of the structures [13]. 


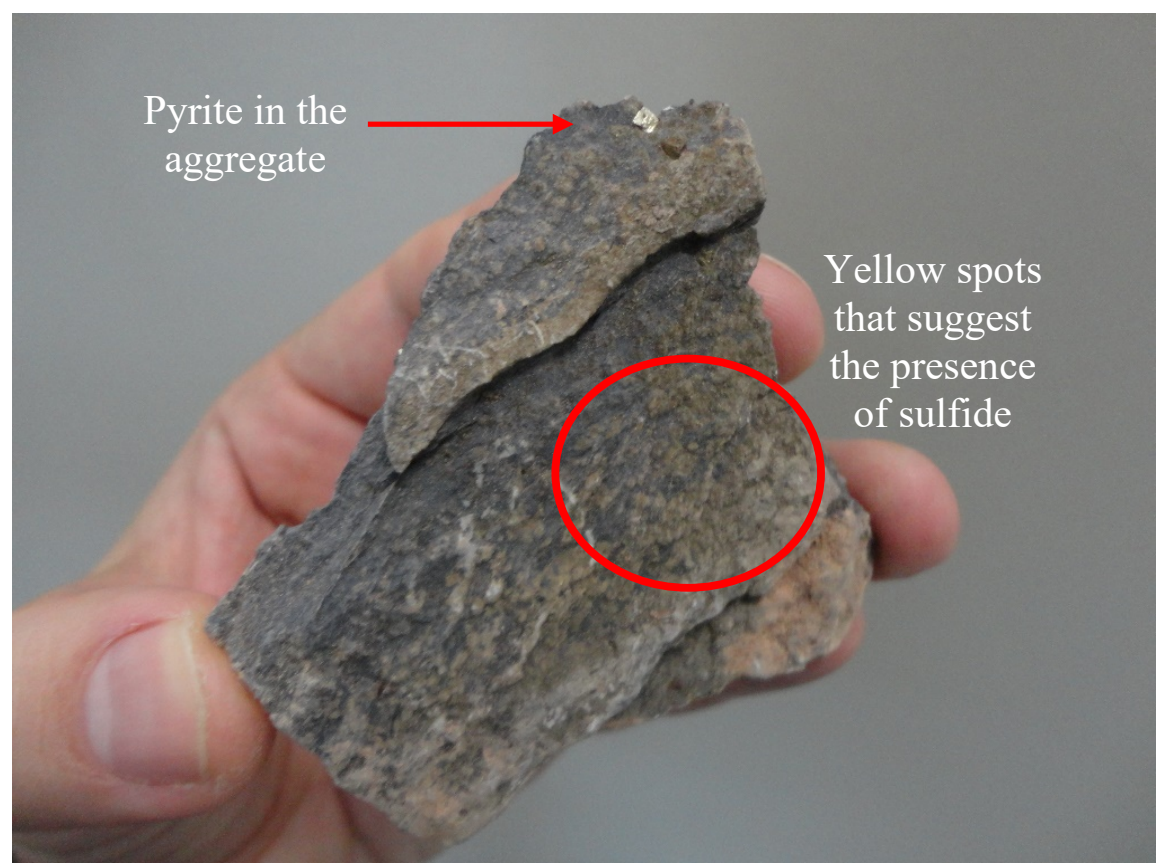

Figure 1. Example of Brazilian civil construction aggregate with verified pyrite contamination and generation of internal sulphatic reaction.

In recent years, studies have been carried out to assess the impacts caused using sulfate-contaminated aggregates.

Goto et al. [16] studied the influence of particle size, $\mathrm{pH}$ of the medium and pyrite concentration on the oxidation of diabase aggregates with sulfide minerals. The results indicated that the reduced grain size and alkaline medium accelerate the oxidation reactions.

Recent studies [17]-[19] related to the attack of sulfates investigate the impact that the presence of contaminants in recycled aggregates, such as gypsum, can cause on the properties of cementitious compounds such as: mechanics, microstructure, and porosity. Analyses analogous to those proposed in these studies were performed in the present study.

Other research has used artificial simulation for an environmental exposure more favorable to attack. The results indicate degradation in the microstructure of cementitious compounds due to the presence of sulfate, caused by the formation of expansive products and the consumption of hydrated products. Degradation in the mechanical properties was also noted by the reduction of the dynamic elastic modulus [20]. Similarly, this research also proposes an accelerated analysis of the internal attack of sulfates and aims to identify the expansive products and the consumption of the hydrated phases through the XRD and SEM tests.

Capraro et al. [21] studied the impact of internal sulfate attack on reinforcement corrosion. The results indicated a greater susceptibility to corrosion in the series with the highest contamination in the study $\left(5.0 \% \mathrm{SO}_{3}\right)$, due to the consumption of portlandite and the chemical instability in the series.

The study of the use of aggregates with the presence of sulfides in cementitious compounds is of great importance, since the presence of contaminates has an influence on the properties of the materials. It is also worth noting that, due to the need to use these aggregates, a limit of contamination that does not damage the properties of concrete structures must be established.

\section{EXPERIMENTAL PROCEDURES}

Molding cement pastes contaminated by different sulfate contents was a method used in the experimental campaign. After the curing period (28 days), the pastes were submitted to a favorable exposure condition for the occurrence of the attack: wetting and drying cycles. The materials were evaluated until 720 days of age in the tests of compressive strength, ultrasonic pulse velocity, porosity, SEM, and XRD. 


\subsection{Materials and mixture characteristics}

The binder used in this experiment is a mixture composed of $65 \%$ Portland cement of high initial strength (CP V ARI - NBR 5733 [22] equivalent to Type III - ASTM C150 [23]) and 35\% fly ash (equivalent to ASTM C618 [24] class F). Table 1 shows the properties of the Portland cement and the fly ash using the X-Ray fluorescence technique.

Table 1. Chemical characterization (\%) of cement and mineral addition.

\begin{tabular}{ccc}
\hline & Cement (CP V ARI) & Fly ash \\
\hline $\mathrm{CaO}$ & 60 & 5.60 \\
\hline $\mathrm{SiO}_{2}$ & 19.58 & 26.60 \\
\hline $\mathrm{Al}_{2} \mathrm{O}_{3}$ & 4.88 & 6.70 \\
\hline $\mathrm{Fe}_{2} \mathrm{O}_{3}$ & 2.85 & 0.80 \\
\hline $\mathrm{MgO}$ & 4.37 & 0.30 \\
\hline $\mathrm{SO}_{3}$ & 2.82 & 3.80 \\
\hline $\mathrm{K}_{2} \mathrm{O}$ & - & 0.80 \\
\hline $\mathrm{Na}_{2} \mathrm{O}$ & - & 1.60 \\
\hline $\mathrm{TiO}_{2}$ & - & - \\
\hline Free $\mathrm{CaO}$ & 0.87 & - \\
\hline Ignition loss & 2.97 & - \\
\hline Insoluble waste & 0.88 & - \\
\hline Alkaline equivalent & 0.78 & \\
\hline
\end{tabular}

The final composite cement is close to the CP IV cement of the Brazilian standard [25] and the Type IV cement of the American standard [23]. The specific mass of the cement and the fly ash, obtained in conformity with ASTM C188 [26], are $3.14 \mathrm{~g} / \mathrm{cm}^{3}$ and $1.95 \mathrm{~g} / \mathrm{cm}^{3}$, respectively.

The contaminant used for the cement paste mixture was pyrite $\left(\mathrm{FeS}_{2}\right)$, a remainder of mineral coal processing. In this study, only one degree of particle size of the contaminated material was analyzed. The influence of the fineness of pyrite on the kinetics of the attack by internal sulfates was not evaluated. A hammer mill carried out the crushing of the contaminated material, and the passage of all the material through the $2.4 \mathrm{~mm}$ sieve was the condition to stop the activity.

The pyrite used has a specific mass of $4.95 \mathrm{~g} / \mathrm{cm}^{3}$, obtained in conformity with ASTM C128 [27], and the diffractogram of the material is shown in Figure 2.

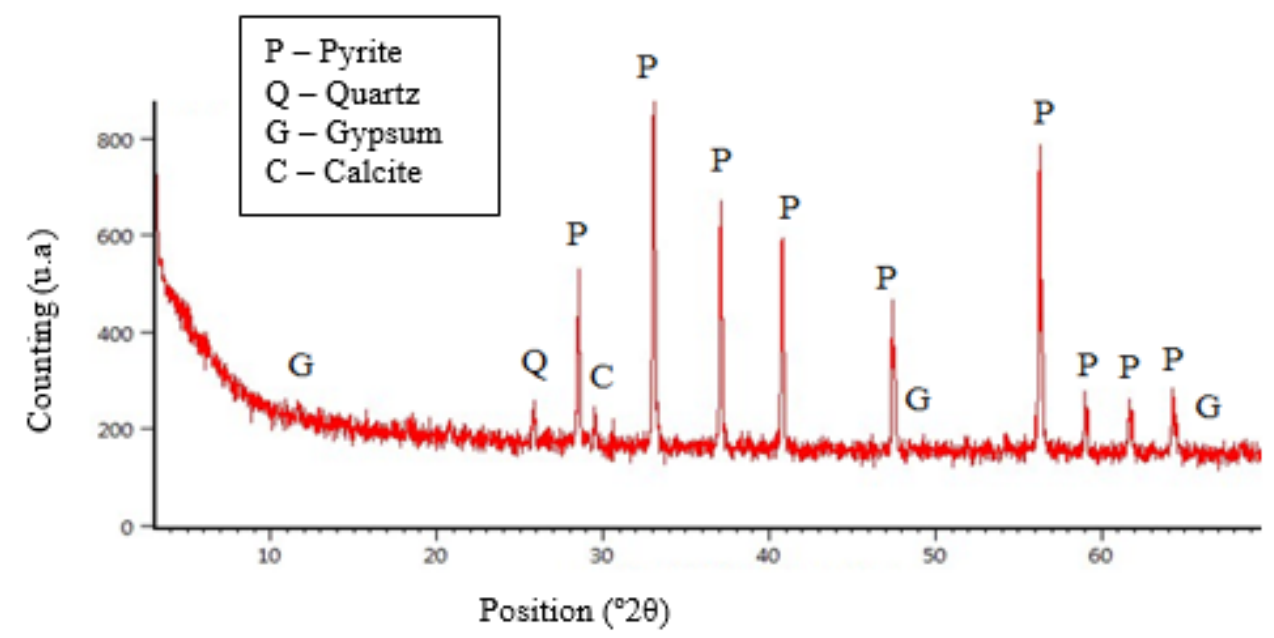

Figure 2. X-Ray Diffractogram of pyrite. 
The limits of internationally disseminated regulations determined the levels of contamination chosen for the cement pastes. Considering that four levels were chosen: $0.0 \% \mathrm{SO}_{3}$ (reference series, without contamination), $0.5 \% \mathrm{SO}_{3}$ (established by the ACI [9]), 1.0\% $\mathrm{SO}_{3}$ (established by the French Standard [10]) and 5.0\% $\mathrm{SO}_{3}$ (higher than allowed by both). The intention of this choice was to evaluate two different levels recommended by current standards and one above those allowed by them.

As the contaminant was pyrite, a calculation of the proportion of mass to determine the equivalent amounts of sulfur quantity between $\mathrm{FeS}_{2}$ and $\mathrm{SO}_{3}$ was necessary. Considering that when oxidized, the pyrite becomes entirely $\mathrm{SO}_{3}$ and performs stoichiometric calculations, it follows that: $\mathrm{FeS}_{2}=0.75 \mathrm{SO}_{3}$.

The previously mentioned standards limit the amount of materials containing sulfides regarding the total mass of aggregates. Since the cement pastes have no aggregate to apply the amounts, a mix proportion of base concrete was used to then determine the amounts regarding the mass of cement.

The concrete mix proportion adopted was: $1.0 \mathrm{~kg}$ of cement, $2.7 \mathrm{~kg}$ of fine aggregate, $2.7 \mathrm{~kg}$ of coarse aggregate and $0.6 \mathrm{~kg}$ of water. The choice of this mix proportion comes from the application of this dosage in the execution of conventional concrete in a hydroelectric plant in Brazil. Contamination percentages were applied over the total mass of aggregates $(2.7 \mathrm{~kg}$ of fine aggregate $+2.7 \mathrm{~kg}$ of coarse aggregate) and determined the proportional contamination regarding the cement mass, according to results presented in Table 2 .

Table 2. Proportional contamination levels.

\begin{tabular}{cccc}
\hline Studied groups & $\begin{array}{c}\text { Contamination content in } \\
\mathbf{S O}_{3}^{*}\end{array}$ & $\begin{array}{c}\text { Contamination content in } \\
\text { Pyrite* }\end{array}$ & $\begin{array}{c}\text { Content of pyrite in relation } \\
\text { to the mass of binder }\end{array}$ \\
\hline Ref. $(0.0 \%)$ & $0.00 \%$ & $0.00 \%$ & $0.00 \%$ \\
\hline $\mathrm{SO}_{3}(0.5 \%)$ & $0.50 \%$ & $0.38 \%$ & $2.05 \%$ \\
\hline $\mathrm{SO}_{3}(1.0 \%)$ & $1.00 \%$ & $0.75 \%$ & $4.05 \%$ \\
\hline $\mathrm{SO}_{3}(5.0 \%)$ & $5.00 \%$ & $3.75 \%$ & $20.25 \%$ \\
\hline
\end{tabular}

* in relation to the total mass of aggregates

The applied contaminant was used as an addition to the cement pastes. However, an inert material (limestone filler) was used to compensate the volumes of the mixtures in order for the four series to have the same cement consumption, allowing the evaluation of the mechanical properties between them.

The limestone filler has a specific mass of $2.84 \mathrm{~g} / \mathrm{cm}^{3}$ and bulk density of $0.85 \mathrm{~g} / \mathrm{cm}^{3}$.

The mix proportion of four cement pastes was presented in Table 3. The cement consumption is the same for all groups, being equal to $973.8 \mathrm{~kg} / \mathrm{m}^{3}$.

Table 3. Mix proportion for the four studied groups.

\begin{tabular}{ccccc}
\hline Studied groups & Binder*(g) & Pyrite $(\mathbf{g})$ & Limestone filler $(\mathbf{g})$ & water/binder* \\
\hline Ref. $(0.0 \%)$ & 1000 & $0 \mathrm{~g}$ & 115 & 0.6 \\
\hline $\mathrm{SO}_{3}(0.5 \%)$ & 1000 & $20 \mathrm{~g}$ & 104 & 0.6 \\
\hline $\mathrm{SO}_{3}(1.0 \%)$ & 1000 & $40 \mathrm{~g}$ & 92 & 0.6 \\
\hline $\mathrm{SO}_{3}(5.0 \%)$ & 1000 & $200 \mathrm{~g}$ & 0 & 0.6 \\
\hline
\end{tabular}

*binder $=(65 \%)$ cement CPV ARI + (35\%) fly ash.

\subsection{Experimental procedure}

\subsubsection{Specimen preparation and exposure conditions}

For the compressive strength and ultrasonic pulse velocity tests, $4 \times 4 \times 16 \mathrm{~cm}^{3}$ prismatic samples were molded, in conformity with NBR 13276 [28]. To statistically analyze the results, 5 specimens were molded for each group at each age analyzed using the Tukey test (95\% confidence). For the porosity, SEM and XRD tests, little cylindrical samples were molded, each with a diameter of $1.5 \mathrm{~cm}$ and a height of $0.5 \mathrm{~cm}$. 
The cement pastes were mixed following the methodology: the water was added to the bowl mixer and the previously homogenized solid materials (binder + filer limestone + pyrite) were released. The materials were mixed for 6 minutes with the equipment operated at the lowest speed. When the mixing was finished, the molds were filled.

The cement paste was poured in the molds $\left(4 \times 4 \times 16 \mathrm{~cm}^{3}\right)$ gradually, in three steps. After each step, the material was manually compacted. The cement paste cylinders used for porosity, SEM and XRD tests were molded in $20 \mathrm{ml}$ plastic bottles. The specimens were demolded 24 hours later, after which they were cured, being submerged in lime saturated water for 28 days. The objective was for the cement pastes to reach an advanced hydrated condition.

After the submerged cure, all the specimens were submitted to wetting and drying cycle conditions. The cycle consisted of the weekly exchange of specimens between a tank that was constantly aerated by pump-water, and a dry chamber with controlled temperature $\left(23 \pm 2^{\circ} \mathrm{C}\right)$ and humidity $(\leq 50 \%)$.

The alternating wetting and drying cycle were carried out in other studies with the objective of accelerating the deleterious reactions, due to the greater availability of water and oxygen [29]-[31].

\subsubsection{Performed tests}

For 720 days the cement pastes were evaluated in laboratory tests. The prismatic specimens were used for the test of compressive strength and ultrasonic pulse velocity. In both tests the specimens were tested in a saturated dry surface condition. The analysis ages of the compressive strength test were: $28,84,168,360$ and 720 days. For the ultrasonic pulse velocity, because it is non-destructive, analyses were performed at all ages already mentioned and also at 1,7 , $56,112,140,210$ days.

The first test to be performed was the ultrasound pulse velocity test, because it was non-destructive. For the test, Proceq Ultrasonic Pulse Velocity - Pundit Lab was used. The $250 \mathrm{kHz}$ transducer was used, according to the fabricator's recommendations for the size of the specimen faces $\left(4 \times 4 \mathrm{~cm}^{2}\right)$. The test was performed in accordance with ASTM C597 [32].

After the ultrasound readings, the compression strength test was performed in accordance with NBR 13279 [33].

Samples used for the porosity, SEM and XRD tests underwent a hydration stoppage process at the test ages $(28,84$, 168, 360 and 720 days for the porosity test, 360 and 720 days for the SEM test and 28 and 720 days for XDR test). The process consisted of the immersion of the samples in pure ethyl alcohol for 24 hours, and later, placing them in an oven at $40^{\circ} \mathrm{C}$ for another 24 hours. The procedure followed that described by Pan et al. [34] and Hoppe et al. [35].

The porosity test consisted of obtaining the total porosity of the sample [36]. The difference between the saturated sample mass (immersed in water for 24 hours) and the dry sample mass (oven dried at $40^{\circ} \mathrm{C}$ for 24 hours) is divided by the difference between the saturated sample mass (immersed in water for 24 hours) and the submersed sample mass, determined in hydrostatic condition. After the process, the samples were stored in a gel silica desiccator.

Microscopy images were obtained with a Tescan SEM FEG microscope, Mira 3 and Oxford X-Max 50 X-ray analytical microprobe (EDS). First, the samples were glued to the stub with graphite enamel for the identification of the elements by EDS. Afterwards, they were removed from the equipment, metalized with gold, and the images were obtained. The gold metallization was not carried out from the beginning to avoid overlapping elements during the obtaining of the EDS spectra.

X-ray diffraction analysis was performed with the powdered samples, which were sprayed with pistil until being passed through the $200 \mu \mathrm{m}$ mesh. The equipment used in the test had $40 \mathrm{kV} / 30 \mathrm{~mA}$ of power and the start and end position of the test were: Start Position [ ${ }^{\circ}$ 2Th.] 5.0084 and End Position [ ${ }^{\circ} 2 \mathrm{Th}$.] 74.9634.

\section{RESULTS AND DISCUSSION}

\subsection{Ultrasonic pulse velocity test}

Figure 3 shows the ultrasonic pulse velocity results. The studied parameter presented great evolution for all the analyzed series, close to $2250 \mathrm{~m} / \mathrm{s}$ at one day of age and $3500 \mathrm{~m} / \mathrm{s}$ at 720 days.

The increase in ultrasonic pulse velocity over the analyzed ages indicates the densification of the matrices. There is a great evolution for all the series until 84 days of age, and after that, small fluctuations and stabilization of the values are noticed. The initial growth was expected, since the occurrence of hydration reactions causes a trend of water consumption and product formation, buffering the pores and decreasing the matrix voids. The same behavior was observed and justified by Godinho et al. [37]. 


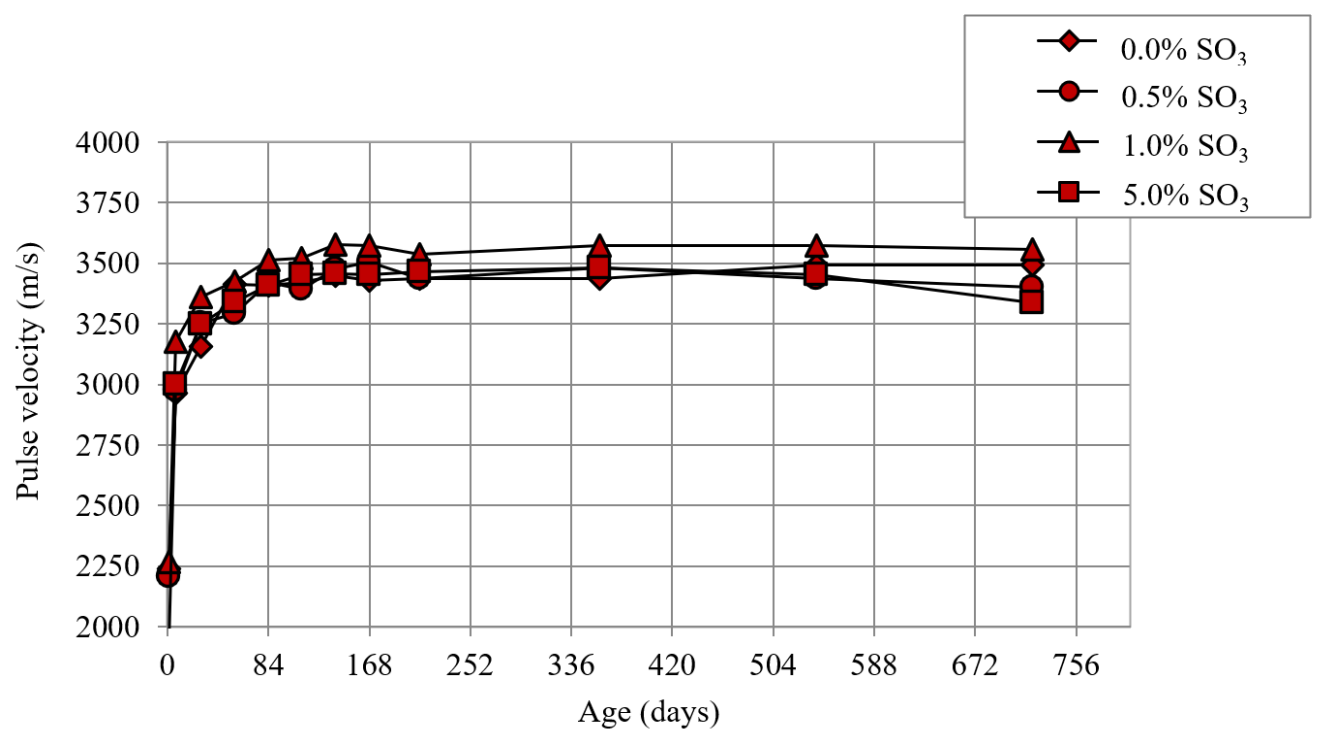

Figure 3. Pulse velocity monitoring for the series $\left(0.0 \%, 0.5 \%, 1.0 \%\right.$ and $\left.5.0 \% \mathrm{SO}_{3}\right)$.

Based on the Tukey test, the series could be considered statistically equivalent in practically the whole study. At 720 days of age, the $0.5 \% \mathrm{SO}_{3}$ and $5.0 \% \mathrm{SO}_{3}$ series showed a small decrease, which made them statistically smaller when compared to the $0.0 \% \mathrm{SO}_{3}$ and $1.0 \% \mathrm{SO}_{3}$.

The fact that the $1.0 \% \mathrm{SO}_{3}$ series presents some of the highest values for the ultrasonic pulse velocity can indicate the densification of the matrix, generated by the filling of the pores and fissures by the products of the deleterious reactions, a clue already observed and reported by Biczók [38] and Ouyang et al. [39].

However, the $0.5 \% \mathrm{SO}_{3}$ series showed a reduction in propagation of ultrasonic pulse velocity. Therefore, in this case the ultrasound test was not a suitable technique to identify the degradation by internal sulfate in the studied period of time.

The pulse velocity test can be used to evaluate the dynamic elastic modulus of cementitious compounds. Chen et al. [20] indicated in their study that, at an early age, the formation of expansive products and consumption of hydrated products caused an increase in the dynamic elastic modulus. However, at advanced ages, the same study reported a reduction in modulus, similar to what occurred in this study for the $5.0 \% \mathrm{SO}_{3}$ series.

\subsection{Compressive strength}

At the first analyzed age, 28 days, the series of higher contaminations $\left(1.0 \%\right.$ and $\left.5.0 \% \mathrm{SO}_{3}\right)$ were responsible for the higher compressive strength. At that age, the series Ref. $(0.0 \%)$ and $0.5 \% \mathrm{SO}_{3}$ were considered statistically equivalent by the Tukey test, as well as the $1.0 \% \mathrm{SO}_{3}$ and $5.0 \% \mathrm{SO}_{3}$ series. The higher values of compressive strength for the series of higher contamination, at an initial age, can be justified by the initial filling of the pores by products from the sulfate attack. This agrees with Araujo [40], since the formation of the products from the internal sulfate attack in the voids filled the spaces, promoting the increase of compressive strength in an initial stage. Figure 4 shows the compressive strength results for all studied ages.

At 84 days of age, all series presented increased compressive strength when compared to the results at 28 days. The result was expected, since the cement used in the cement pastes had a high percentage of pozzolanic addition (35\%). At that age, the $1.0 \% \mathrm{SO}_{3}$ series remained that with the highest compressive strength, followed by the others, which were equivalent to each other.

From 168 days up to 720 days, the Ref. $(0.0 \%), 0.5 \% \mathrm{SO}_{3}$ and $1.0 \% \mathrm{SO}_{3}$ series showed neither increase nor reduction of compressive strength, remaining constant. The three series were considered statistically similar at all three ages.

The $5.0 \% \mathrm{SO}_{3}$ can be considered similar to the others at the age of 168 and 360 days. However, at the age of 720 days, it was considered similar only to $0.5 \% \mathrm{SO}_{3}$ and $1.0 \% \mathrm{SO}_{3}$, with lower compressive strength when compared to the reference series (approximately 12\% lower). This indicates that, for this degree of contamination, the reaction products may have filled the pores and caused enough stresses to microcrack the cementitious matrix. 


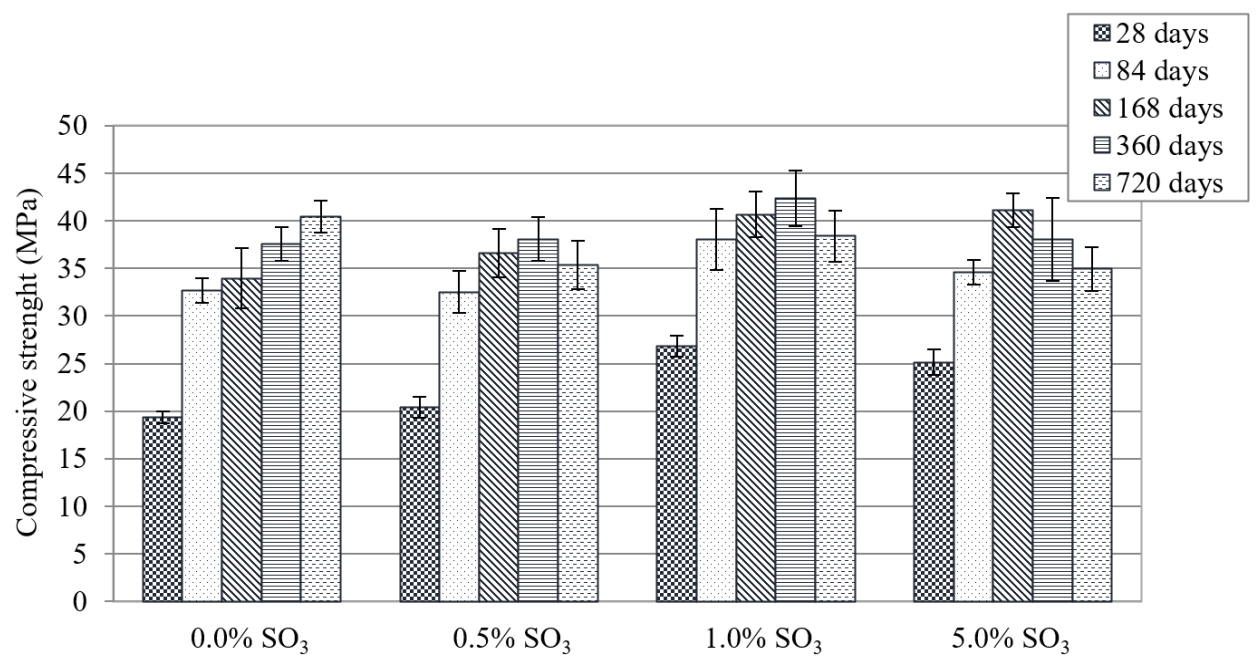

Figure 4. Compressive strength monitoring for the series $\left(0.0 \%, 0.5 \%, 1.0 \%\right.$ and $\left.5.0 \% \mathrm{SO}_{3}\right)$.

In the last studied age, a tendency of strength decreases for the three contaminated series $\left(0.5,1.0\right.$ and $\left.5.0 \% \mathrm{SO}_{3}\right)$ is noticed, which did not happen for the reference series.

Similarly, Xiao et al. [41] demonstrated that the higher the content of substitution of natural aggregate for recycled aggregate with the presence of sulfur, the lower the compressive strength of mortars.

\subsection{Total porosity}

Similar to that observed in the previously presented tests, the results of porosity indicated a higher densification of the matrix at initial ages in the series of greater contamination $\left(1.0 \%\right.$ and $\left.5.0 \% \mathrm{SO}_{3}\right)$. The porosity of samples exposed to sulfates is also discussed by Zou et al. [42]. The authors justify the reduction in the property at an early age by the refinement of the pores, caused by the products created in the chemical reactions with the sulfate.

Figure 5 shows the results for the total porosity. Throughout all ages, the series $0.0 \%$ and $0.5 \% \mathrm{SO}_{3}$ were considered statistically equivalent, as were the series $1.0 \%$ and $5.0 \% \mathrm{SO}_{3}$.

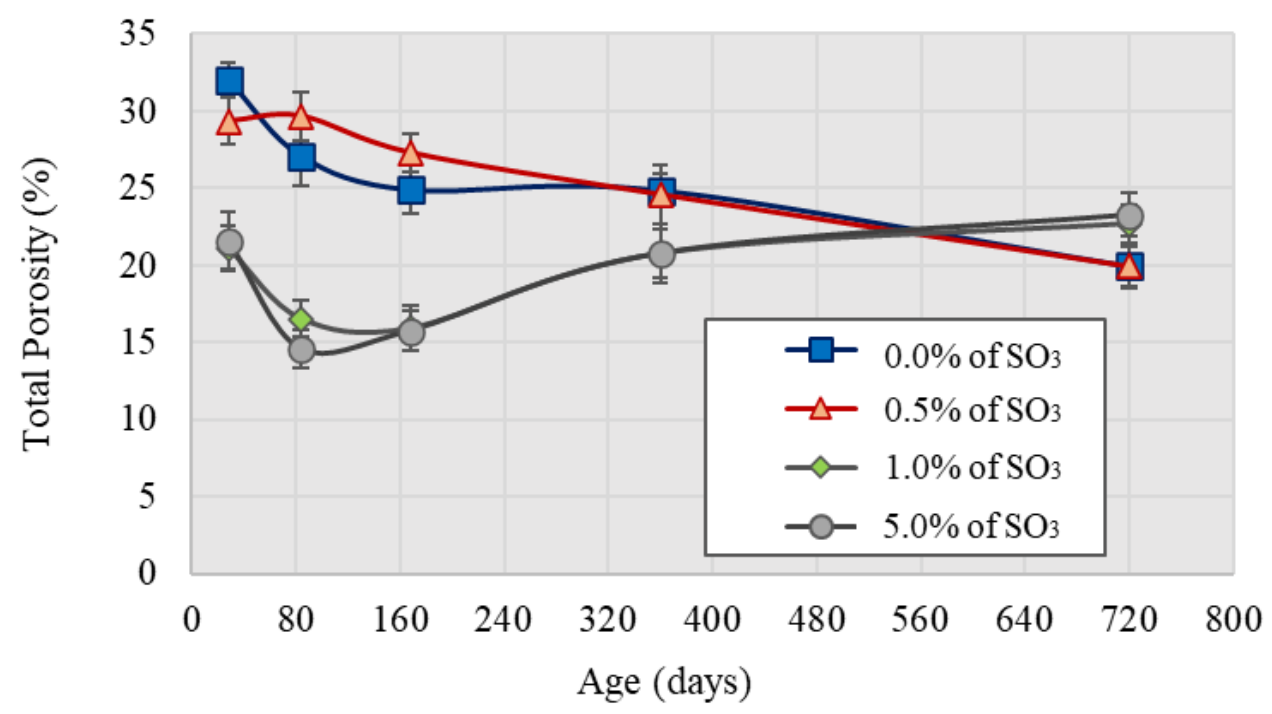

Figure 5. Total porosity monitoring for the series studied $\left(0.0 \%, 0.5 \%, 1.0 \%\right.$ and $\left.5.0 \% \mathrm{SO}_{3}\right)$. 
For the $0.5 \%$ content, there was no interference in the apparent porosity of the cement paste. For the contents of $1.0 \%$ and $5.0 \%$, there was a significant reduction in porosity up to the age of 168 days due to the formation of ettringite/gypsite. Although there are still empty spaces available at this age, the microstructure became subjected to internal stresses, which caused the cracking of the matrix and thereby progressively increased the porosity of cement pastes. For the $1.0 \%$ content, despite the progressive increase of the porosity since the age of 168 days, the compressive strength was not affected, and its decrease was observed only after 360 days. For the $5.0 \%$ content, the increase in porosity after 168 days caused a decrease in the compressive strength at the same age.

Thus, in the last analyzed age (720 days) there was inversion of the behavior of the parameter evaluated, since the series with $1.0 \%$ and $5.0 \%$ presented higher porosity. The series of higher contaminations $\left(1.0 \%\right.$ and $\left.5.0 \% \mathrm{SO}_{3}\right)$ had the highest porosities, indicating a possible fragility of the matrix. Yan et al. [43] observed a similar behavior in samples exposed to $\mathrm{Na}_{2} \mathrm{SO}_{4}$ solution (external sulfate attack). At initial ages (up to 180 days) samples exposed to $5 \% \mathrm{Na}_{2} \mathrm{SO}_{4}$ solution presented smaller porosities than those exposed to the reference solution (confirmed by the crystallization of deteriorating products in the pores). At advanced ages (540 days), with the advance of the attack, the samples had larger porosities than the references.

Sun et al. [44] also demonstrated in their study that at an initial period, there is a decrease in the porosity of concretes exposed to sulfate solubilities. However, since the age of 20 days of exposure, they noticed an increase in porosity. The authors associate porosity reduction with the formation of ettringite and gypsum in concrete pores. In this work, the SEM and XRD tests were done to prove the products related to the initial increase in porosity.

Thus, according to the studies of Yan et al. [43], in the series of higher contamination (5\%), porosity reduction up to 300 days should occur due to the formation of ettringite and gypsite crystals in the concrete pores. On the other hand, the porosity increase after this period must have occurred due to the appearance of microcracks caused by the complete filling of the pores and the generation of internal stresses. The SEM test with EDS was used in this work to prove this theory.

\subsection{SEM and EDS}

Comparable to what was observed in other studies, the SEM images indicated the presence of acicular crystals, similar to those of ettringite, for the contaminated cementitious pastes.

In their study, Ayora et al. [5] indicate the deposition of products such as gypsum or ettringite in the pores of concretes with advanced stage of alteration by the presence of sulfides. Campos et al. [45] used the SEM technique to verify the occurrence of the internal attack of sulfates in a dam in Spain. Once again, the presence of ettringite and gypsum is a indicative factor of the occurrence of the advanced stage attack.

In this work, an analysis of the evolution of pore filling was carried out, considering the different contamination levels. For this analysis, it was necessary to work with the same magnification for all series, $4 \mathrm{kx}$, since the pores should have similar dimensions for comparative effect.

Figure $6 \mathrm{~A}$ shows that at 360 days of age, the Ref. $\left(0.0 \% \mathrm{SO}_{3}\right)$ series still had free pores inside. The pore, approximately $40 \mu \mathrm{m}$ in diameter, had no product deposited inside.

On the other hand, the $0.5 \% \mathrm{SO}_{3}$ group (Figure $6 \mathrm{~B}$ ) showed some acicular crystals with a shape like that of ettringite (indicated by the arrow) within the observed pore. However, there is a small amount of these, which would not justify a filling for the elevation of compressive strength at the early stages of the attack.

For the $1.0 \% \mathrm{SO}_{3}$ group, the pore found was approximately $20 \mu \mathrm{m}$, as observed in Figure 6C. However, it appeared with a much higher filling due to deposited acicular crystals (indicated by the arrow), evidence of the occurrence of generating reactions of the ettringite in the porous structure of this test series. The filling of the pore of the mentioned series corroborates with the results of addition of compressive strength and reduction of porosity at early ages, already discussed beforehand.

The pore analyzed for the $5.0 \% \mathrm{SO}_{3}$ series, Figure $6 \mathrm{D}$, was the one that presented greater filling by more defined crystals of ettringite.

The EDS analysis of the point highlighted in Figure 6D (5.0\% $\mathrm{SO}_{3}$ series), presented in Table 4, confirms the presence of ettringite in the analyzed area. This can be confirmed because the elements found in the EDS have exceeded the theoretical percentages of the elements of the ettringite (remaining contents). 

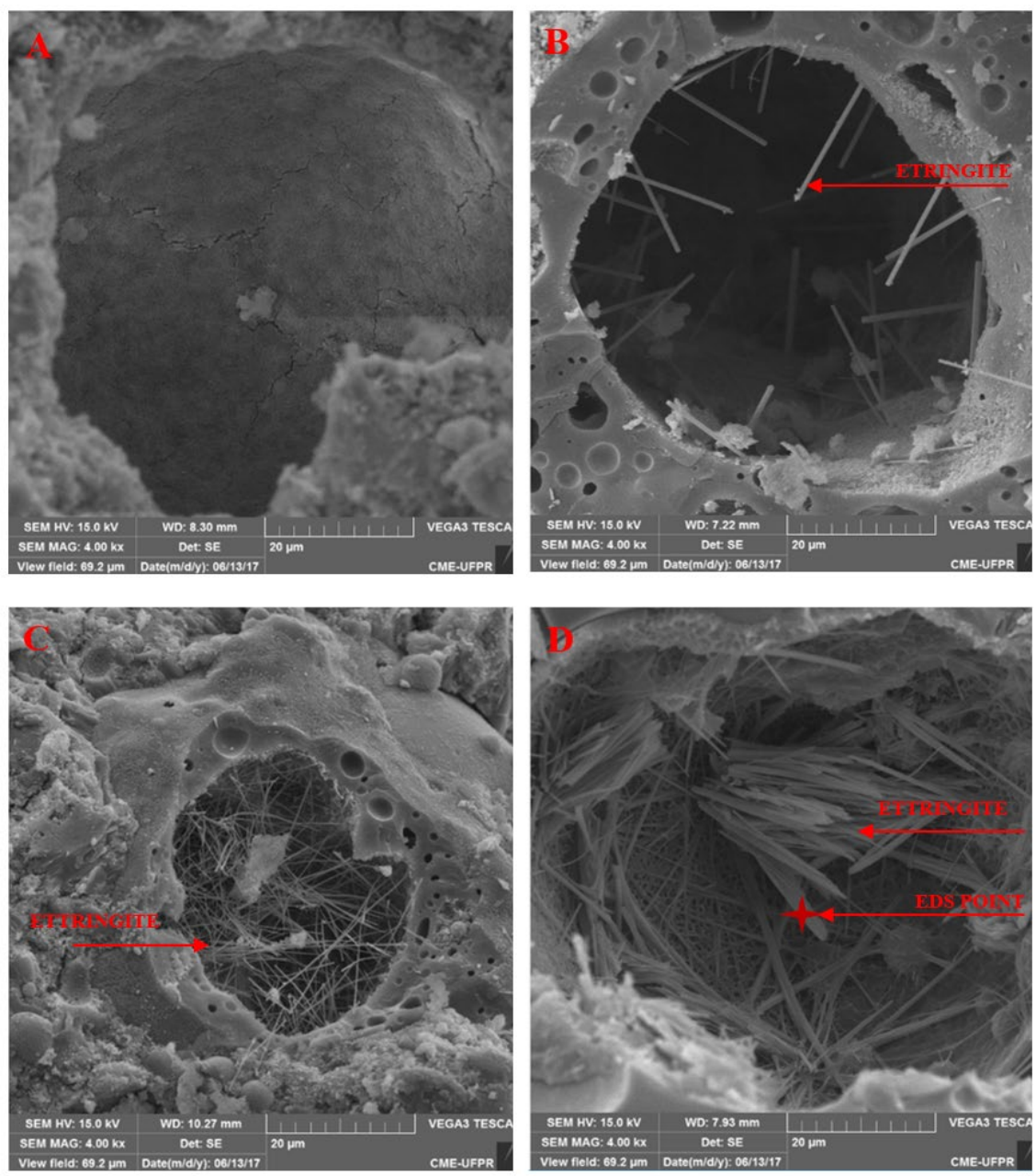

Figure 6. Comparative analysis of pore evolution for the series studied (A - 0.0\%, B - 0.5\%, C - 1.0\% and D - 5.0\% $\left.\mathrm{SO}_{3}\right)$ at 360 days of age.

Table 4. Proportion of elements for EDS analysis of ettringite.

\begin{tabular}{ccccc}
\hline Elements & $\begin{array}{c}\text { Theoretical percentage } \\
\text { of ettringite elements }\end{array}$ & $\begin{array}{c}\text { Percentages obtained } \\
\text { in EDS }\end{array}$ & $\begin{array}{c}\text { Adoption of the } \\
\text { critical content (Al) }\end{array}$ & Remaining contents* \\
\hline $\mathrm{Ca}$ & $19.13 \%$ & $23.30 \%$ & $12.50 \%$ & $10.80 \%$ \\
$\mathrm{Al}$ & $4.30 \%$ & $2.80 \%$ & $2.80 \%$ & $0.00 \%$ \\
\hline $\mathrm{S}$ & $7.67 \%$ & $5.70 \%$ & $5.00 \%$ & $0.70 \%$ \\
$\mathrm{O}$ & $63.74 \%$ & $50.10 \%$ & $41.50 \%$ & $8.60 \%$ \\
\hline $\mathrm{H}$ & $5.14 \%$ & - & - & - \\
\hline
\end{tabular}

*Difference between the percentages obtained in the EDS and the adoption of the critical content

The comparative analysis between the four images shows that the higher the content of the contaminant used in the mixtures, the greater the matrices are compromised.

At 720 days of age, the presence of cracks (indicated by the arrow) near the pores was observed in the series of higher contamination $\left(5.0 \% \mathrm{SO}_{3}-\right.$ Figure $\left.6 \mathrm{~B}\right)$, indicating a possible fragility of the matrix due to the high contaminant content. In their study, Kazmi et al. [18] also showed the presence of cracks in samples contaminated by sulfate, justified by the stress caused by the generation of expansive products.

The continued presence of acicular crystals in the most contaminated series (Figure 7B) is indicative of the attack. Under normal conditions, as previously noted for the reference series, healthy cementitious compositions tend not to 
present crystals of ettringite. This is because without a new source of sulfate, the primary ettringite becomes monosulfoaluminate (AFm) [46], having a different morphology and volume.

The images of Figure 6 shows that in initial stages up to one year of age, there is deposition of products in the pores of concretes contaminated by sulfides. These results confirm the one mentioned in the other tests: increase of compressive strength and drop in the porosity of the series with higher contamination $\left(1.0 \%\right.$ and $\left.5.0 \% \mathrm{SO}_{3}\right)$. However, at 720 days, in the case of this study, images with the appearance of cracks could already be observed for the series of greater contamination. The observed cracks are the consequence of tensions generated by the deleterious products, also confirmed by the decrease of resistance, and increase of the porosity in the $1.0 \%$ and $5.0 \% \mathrm{SO}_{3}$ series. In the reference series at that same age, the cracks noted in the $5.0 \% \mathrm{SO}_{3}$ series were not identified (Figure 7A).
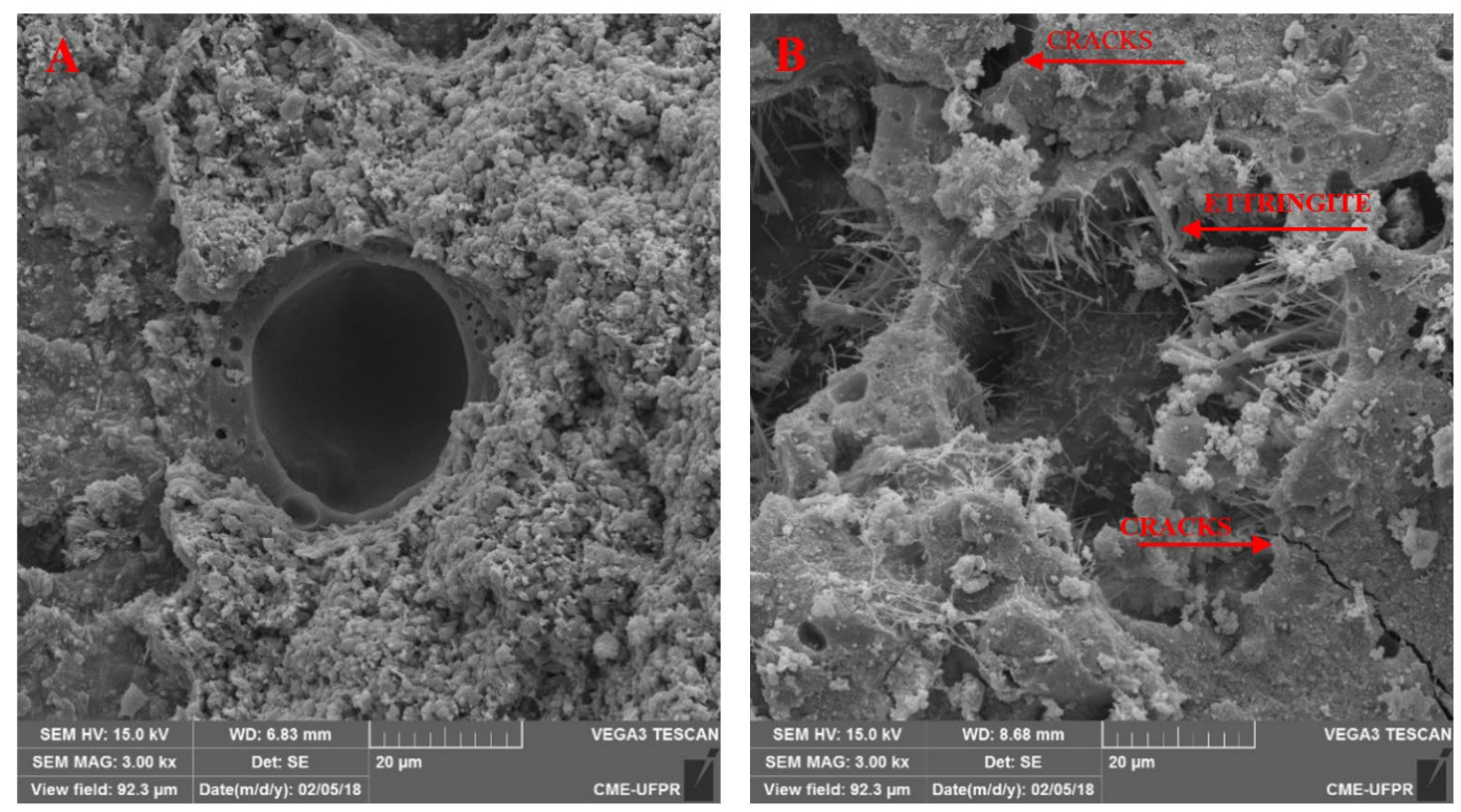

Figure 7. Images obtained at 720 days from reference and 5.0\% $\mathrm{SO}_{3}$ series. A - Reference series with pore free of products and without cracks. $\mathrm{B}-5.0 \% \mathrm{SO}_{3}$ series with ettringite and cracks.

\subsection{XRD}

The XRD confirmed the higher presence of ettringite in the series of higher contamination $\left(5.0 \% \mathrm{SO}_{3}\right)$. The behavior of the reference series, the $0.5 \%$ and the $1.0 \% \mathrm{SO}_{3}$ were similar in terms of identified products and peak intensity. Figure 8 presents a comparative analysis between the reference sample (Ref. $0.0 \% \mathrm{SO}_{3}$ ) and the sample of higher contamination $\left(5.0 \% \mathrm{SO}_{3}\right)$ at 28 and 720 days of age. Figure $8 \mathrm{~A}$ and $\mathrm{B}$, both of Ref. $\left(0.0 \% \mathrm{SO}_{3}\right)$ shows that there was no difference in the intensity of the main ettringite peak $\left(9.01^{\circ}\right)$ when compared to both ages, with the intensities close to 1100 days. The same did not occur with the $5.0 \% \mathrm{SO}_{3}$ series (Figure $8 \mathrm{C}$ and $\mathrm{D}$ ), which since 28-days of age (Figure 8A versus Figure 8C) presented the greatest intensity when compared to the reference (1100 versus 1300), and showed an increase between the ages of 28 and 720 days (1300 versus 1400), indicating the formation of ettringite over time in that series.

The high concentration of ettringite in materials attacked by sulfates has also been confirmed in other studies, justifying the expansion tensions caused by the attack [17], [18], [42], [47].

According to Souza et al. [48], ettringite peaks with greater intensity were found in mortars exposed to sulfatecontaminated solutions $\left(\mathrm{Na}_{2} \mathrm{SO}_{4}\right.$ and $\left.\mathrm{MgSO}_{4}\right)$. 

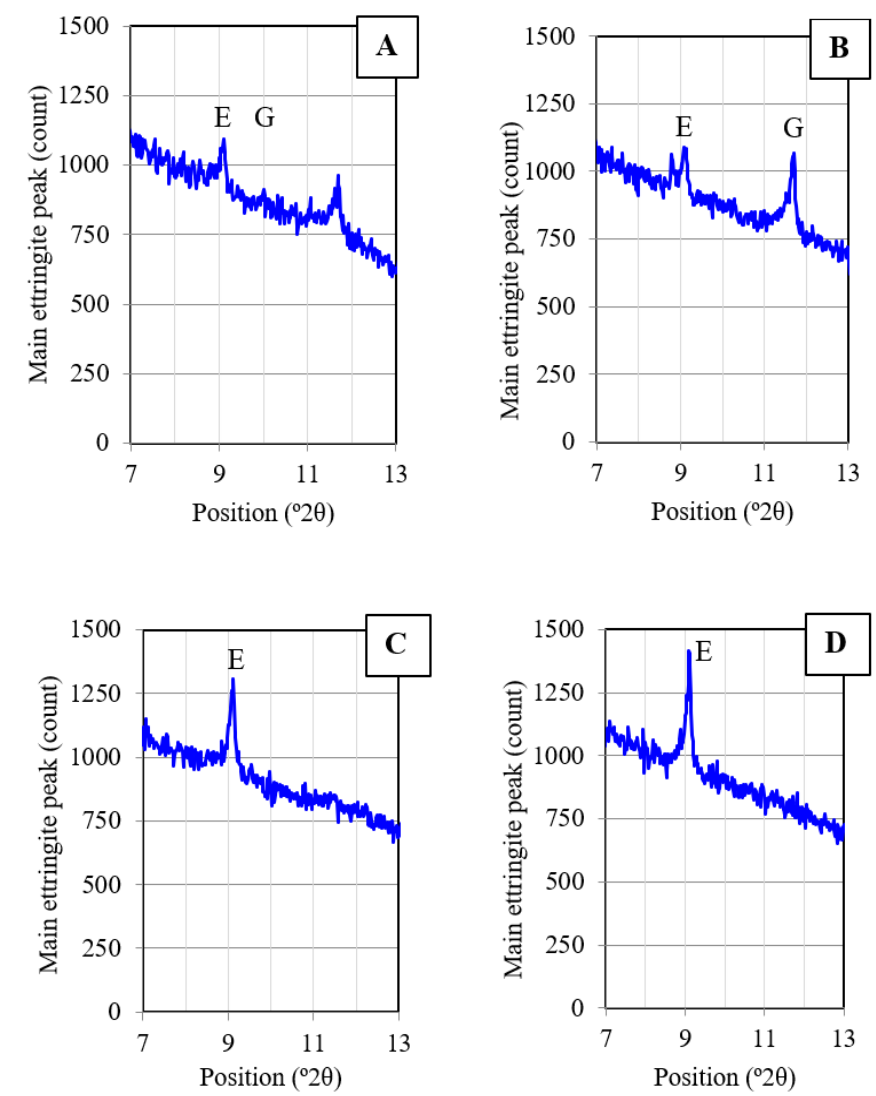

Figure 8. Comparative analysis of the main ettringite (E) peak in the diffractograms. A - Ref. $\left(0.0 \% \mathrm{SO}_{3}\right)$ at 28 days; $\mathrm{B}$ - Ref. $\left(0.0 \% \mathrm{SO}_{3}\right)$ at 720 days; $\mathrm{C}-\left(5.0 \% \mathrm{SO}_{3}\right)$ at 28 days; $\mathrm{D}-\left(5.0 \% \mathrm{SO}_{3}\right)$ at 720 days. $(\mathrm{E}$ - ettringite; $\mathrm{G}-\mathrm{Gypsum})$

\section{CONCLUSIONS}

The different levels of contamination evaluated in this study allowed the comparative analysis of the properties of the cementitious pastes, indicating greater damages to the pastes with higher levels of contamination.

The development of the research described in this work has led to the following conclusions:

- At the initial ages of the compounds, up to 168 days, the contamination levels of $1.0 \%$ and $5.0 \% \mathrm{SO}_{3}$ were responsible for the increase of mechanical resistance and decrease of the porosity of the materials. This behavior is justified by the chemical reactions resulting from the presence of sulfates.

- At 720 days of age, the series with $5.0 \% \mathrm{SO}_{3}$ was the one with the lowest compressive strength, being approximately $13 \%$ lower than the reference series at the same age and $10 \%$ lower than its own strength at the previous age.

- All the contaminated series showed strength drop from 360 to 720 days, ranging from $5.4 \%$ for $0.5 \% \mathrm{SO}_{3}, 9.5 \%$ for $1.0 \% \mathrm{SO}_{3}$ and $10.2 \%$ for $5.0 \% \mathrm{SO}_{3}$. The reduction in mechanical properties proves the importance in defining a maximum contamination content to be accepted.

- The porosity test showed a change in its tendency at 168 days of age. Before, the series of higher contamination $\left(1.0 \%\right.$ and $\left.5.0 \% \mathrm{SO}_{3}\right)$ had the smallest porosities, whereas after that age they had the largest porosities. The higher porosity for these series at the end of the study indicates the fragility in the matrix due to the presence of sulfate, alerting to the levels used in concrete structures.

- The SEM images indicated a larger filling of the pores for the higher contamination contents, confirming the occurrence of the attack and consequent formation of ettringite. In the images, the degree of damage of the sample of $1.0 \%$ and $5.0 \% \mathrm{SO}_{3}$ is evident. The appearance of cracks, evidenced in the SEM, indicates the fragility of the materials and contributes to the results of increased porosity and compressive strength drop;

- The XRD analysis showed a higher presence of ettringite in the series of higher contamination $\left(5.0 \% \mathrm{SO}_{3}\right)$ at 28 days of age. Comparing the age of 28 days to the age of 720 days, an increase in the main peak of ettringite was noticed; 
- The results obtained in this study show the need for standardization of the levels of maximum sulfide contamination allowed for aggregates to be used in concrete structures. The contamination of $5.0 \% \mathrm{SO}_{3}$ showed the worst results in terms of strength, porosity and matrix damage. However, behavioral changes were also noticed for the series of $0.5 \%$ and $1.0 \% \mathrm{SO}_{3}$, levels currently allowed by standards. The use of aggregates with $1.0 \%$ of contamination can be complicated, since the presented results were similar to those of the $5.0 \% \mathrm{SO}_{3}$ series.

\section{ACKNOWLEDGEMENTS}

The authors thank the Araucária Foundation for the support and scholarships. Thanks are also given for the availability of the infrastructure and human resources made available by the Federal University of Paraná (PPGECC/UFPR-Brazil). Our gratitude also goes to the Center of Electron Microscopy of UFPR (CME/UFPR) for the support during the SEM tests.

\section{REFERENCES}

[1] J. Duchesne and B. Fournier, "Deterioration of concrete by the oxidation of sulphide minerals in the aggregate," J. Civ. Eng. Archit., vol. 7, no. 8, pp. 922-931, 2013.

[2] A. Campos, C. M. López, and A. Aguado, "Diffusion-reaction model for the internal sulfate attack in concrete," Constr. Build. Mater., vol. 102, pp. 531-540, 2016.

[3] M. D. A. Thomas, R. J. Kettle, and J. A. Morton, "Expansion of Cement-Stabilized Minestone due to the Oxidation of Pyrite," Geotech. Eng. Transp. Res. Rec., vol. 1219, pp. 113-120, 1989.

[4] I. Casanova, L. Agulló, and A. Aguado, "Aggregate expansivity due to sulfide oxidation - I. reaction system and rate model," Cement Concr. Res., vol. 26, pp. 993-998, 1996.

[5] C. Ayora, S. Chinchón, A. Aguado, and F. Guirado, "Weathering of iron sulfides and concrete alteration: thermodynamic model and observation in dams from Central Pyrenees, Spain," Cement Concr. Res., vol. 28, pp. 1223-1235, 1998.

[6] T. Ikumi, I. Segura, and S. H. P. Cavalaro, "Influence of early sulfate exposure on the pore network development of mortars," Constr. Build. Mater., vol. 143, pp. 33-47, 2017.

[7] T. Schmidt, A. Leemann, E. Galluci, and K. Scrivener, "Physical and microstructural aspects of iron sulfide degradation in concrete," Cement Concr. Res., vol. 41, pp. 263-269, 2011.

[8] N. P. Hasparyk, F. C. Muniz, M. A. S. Andrade, M. J. Gomides, R. M. Bittencourt, and H. Carasek, “A deterioração de estruturas de concreto contend agregados com sulfetos," in Sim. EPUSP Estrut. Concr., 2003.

[9] American Concrete Institute, Guide to Durable Concrete, ACI 201, 1991.

[10] Association Française De Normalisation, Granulats - Définitions, Conformité, Spécifications, XP P18-540, 1997.

[11] Associação Brasileira de Normas Técnicas, Aggregates for Concrete-Specification, NBR 7211, 2009.

[12] A. L. C. Lima, "Influência da presença de sulfetos na implantação da UHE Irapé - Vale do Jequetinhonha - Minas Gerais,” M.S. thesis, Univ. Fed. Ouro Preto, 2009.

[13] I. Oliveira, S. H. P. Cavalaro, and A. Aguado, "New kinetic model to quantify the internal sulfate attack in concrete," Cement Concr. Res., vol. 43, pp. 95-104, 2013.

[14] M. A. Czerewko and J. C. Cripps, Sources of Sulfur Species. Identification and Quantification. Thaumasite and Other Forms of Concrete Deterioration and Protection. Halifax Hall: University of Sheffield, 1999.

[15] A. Tagnit-Hamou, M. Saric-Coric, and P. Rivard, "Internal deterioration of concrete by the oxidation of pyrrhotite aggregates," Cement Concr. Res., vol. 35, pp. 99-107, 2005.

[16] H. Goto et al., "Physicochemical evaluation of oxidation of diabase aggregates with sulfide minerals: influence of particle size, pH of the medium and pyrite concentration," J. Build. Pathol. Rehabil., vol. 1, pp. 1-10, 2016.

[17] C. Colman, D. Bulteel, V. Thiery, S. Rémond, F. Michel, and L. Courard, "Internal sulfate attack in mortars containing contaminated fine recycled concrete aggregates," Constr. Build. Mater., vol. 272, 121851, 2021.

[18] S. M. Kazmi, M. J. Munir, Y. F. Wu, I. Patnaikuni, Y. Zhou, and F. Xing, "Effect of diferente aggregate tratment techiniques on the freeze-thaw and sulfate resistance of recycled aggregate concrete," Cold Reg. Sci. Technol., vol. 178, 103126, 2020.

[19] F. Xie, J. Li, G. Zhao, P. Zhou, and H. Zheng, "Experimental study on performance of cast-in-situ recycled aggregate concrete under different sulfate attack exposures," Constr. Build. Mater., vol. 253, 119144, 2020.

[20] Y. Chen, P. Liu, and Z. Yu, "Study on degradation of macro performances and micro structure of concrete attacked by sulfate under artificial simulated environment," Constr. Build. Mater., vol. 260, 119951, 2020.

[21] A. P. B. Capraro, G. Macioski, and M. H. F. Medeiros, "Effect of aggregate contamination with pyrite on reinforcement corrosion in concrete," Eng. Fail. Anal., vol. 23, pp. 105116, 2020. 
[22] Associação Brasileira de Normas Técnicas, High Early Strength Portland Cement - Specification, NBR 5733, 1991.

[23] American Society for Testing and Materials, Standard Specification for Portland Cement, ASTM C150, 2018.

[24] American Society for Testing and Materials, Standard Specification for Coal Fly Ash and Raw or Calcined Natural Pozzolan For use in Concrete, ASTM C618, 2017.

[25] Associação Brasileira de Normas Técnicas, Pozzolanic Portland Cement-Specification, NBR 5736, 1999.

[26] American Society for Testing and Materials, Standard Test Method for Density of Hydraulic Cement, ASTM C188, 2017.

[27] American Society for Testing and Materials, Standard Test Method for Relative Density and Absorption of Fine Aggregate, ASTM C128, 2015.

[28] Associação Brasileira de Normas Técnicas, Mortars Applied on Walls and Ceilings - Determination of the Consistence Index, NBR 13276, 2016.

[29] J. Gao, Z. Yu, L. Song, T. Wang, and S. Wei, "Durability of concrete exposed to sulfate attack under flexural loading and dryingwetting cycles," Constr. Build. Mater., vol. 39, pp. 33-38, 2013.

[30] J. Gong, J. Cao, and Y. Wang, "Effects of sulfate attack and dry-wet circulation on creep of fly-ash slag concrete," Constr. Build. Mater., vol. 125, pp. 12-20, 2016.

[31] L. Jinag and D. Niu, "Study of deterioration of concrete exposed to different types of sulfate solutions under drying-wetting cycles," Constr. Build. Mater., vol. 117, pp. 88-98, 2016.

[32] American Society for Testing and Materials, Standard Test Method for Pulse Velocity Through Concrete, ASTM C597, 2016.

[33] Associação Brasileira de Normas Técnicas, Mortars Applied on Walls and Ceilings - Determination of the Flexural and the Compressive Strength in the Hardened Stage, NBR 13279, 2005.

[34] Z. Pan, L. Cheng, Y. Lu, and N. Yang, "Hydration products of alkali-activated slag-red mud cementitious material," Cement Concr. Res., vol. 32, pp. 357-362, 2002.

[35] J. Hoppe Fo., C. S. Rodrigues, L. S. O. P. Ribeiro, and M. H. F. Medeiros, "Evaluation of sample drying methods to determine the apparent porosity and estimation of degree of hydration of portland cement pastes," J. Bulding Pathol. Rehabil., vol. 6, pp. 1-11, 2021.

[36] F. Montes, S. Valavala, and L. M. Haselbach, "A new test method for porosity measurements of Portland Cement Pervious Concrete," J. ASTM Int., vol. 2, pp. 1-13, 2005.

[37] J. P. Godinho, T. F. Souza Jr., M. H. F. Medeiros, and M. S. A. Silva, "Factors influencing ultrasonic pulse velocity in concrete," Rev. IBRACON Estrut. Mater., vol. 13, pp. 235-247, 2020.

[38] I. Biczók, Concrete Corrosion and Concrete Protection. New York: Chemical Publishing Company, 1972.

[39] W. Ouyang, J. Chen, and M. Jiang, "Evolution of surface hardness of concrete under sulfate attack," Constr. Build. Mater., vol. 53, pp. 419-424, 2014.

[40] A. Araujo, Corrosion Study in Concrete Structures. Rio de Janeiro: Inst. Technol. Res., 2013.

[41] Q. H. Xiao, Z. Y. Cao, X. Guan, Q. Li, and X. L. Liu, "Damage to recycled concrete with diferente aggregate substituition rates from the coupled action of freeze-thaw cycles and sulfate attack," Constr. Build. Mater., vol. 221, pp. 74-83, 2019.

[42] D. Zou, S. Qin, T. Liu, and A. Jivkov, "Experimental and numerical study of the effects of solution concentration and temperature on concrete under external sulfate attack," Cement Concr. Res., vol. 139, 106284, 2021.

[43] X. Yan, L. Jiang, M. Guo, Y. Chen, Z. Song, and R. Bian, "Evaluation of sulfate resistance of slag contained concrete steam curing," Constr. Build. Mater., vol. 195, pp. 231-237, 2019.

[44] S. Sun, K. Wu, H. Shi, L. Zhang, and L. Zhang, "Effect of interfacial transition zone on the transport of sulfate ions in concrete," Constr. Build. Mater., vol. 192, pp. 28-37, 2018.

[45] A. Campos, C. M. López, A. Blanco, and A. Aguado, "Effects of an internal sulfate attack and an alkali-aggregate reaction in a concrete dam," Constr. Build. Mater., vol. 166, pp. 668-683, 2018.

[46] X. Wang, Z. Pan, X. Shen, and W. Liu, "Stability and decomposition mechanism of ettringite in presence of ammonium sulfate solution," Constr. Build. Mater., vol. 124, pp. 786-793, 2016.

[47] Y. Tian et al., "Internal transport and corrosion behaviors of sulfate corrosion media carried by recycled aggregate in concrete," Constr. Build. Mater., vol. 260, 120480, 2020.

[48] D. J. Souza, A. H. F. Medeiros, and J. Hoppe Fo., "Evaluation of external sulfate attack (Na2SO4 and MgSO4): Portland cement mortars containing siliceous supplementary cementitious materials," Rev. IBRACON Estrut. Mater., vol. 13, no. 4, e13403, 2020.

Author contributions: CAPB: conducting tests, formal analyzing, methodology, writing the article; HFJ: formal analyzing, review of article writing; MMHF: formal analyzing, methodology, review of article writing.

Editors: Mark Alexander, Guilherme Aris Parsekian. 